\title{
Distribution, Enrichment and Accumulation of Heavy Metals in Elemi River Sediments, South-Western, Nigeria
}

\author{
Ibigbami*O.A., Awokunmi E.E., Asaolu S.S \\ ${ }^{1}$ Department Of Chemistry, Ekiti State University, PMB, Ado- Ekiti, Nigeria
}

\begin{abstract}
Water sediments are the final repositories for natural and anthropogenic components of the ecosystem and as a result of this; there is need for constant monitoring of our environment, most importantly River sediments. This research work assesses the anthropogenic contributions of heavy metals in Elemi River sediment with the aid of statistical tools such as Enrichment factor (EF), Pollution load index (PLI) and geoaccumulation index $\left(I_{g e o}\right)$. The distribution patterns were in the order; $\mathrm{Cu}>\mathrm{Zn}>\mathrm{Fe}>\mathrm{Mn}>\mathrm{Pb}>\mathrm{Cd}>\mathrm{Cr}$ during the dry season while the wet season was in the order: $\mathrm{Cu}>\mathrm{Zn}>\mathrm{Mn}>\mathrm{Pb}>\mathrm{Fe}>\mathrm{Cr}>\mathrm{Cd}$. The EF of 1.05 - 4.42 reflects minor enrichment to moderately enrich for all the metals except $\mathrm{Cu}(6.83)$ with moderately severe enrichment. The pollution load index (PLI) and index of geo-accumulation $\left(I_{g e o}\right)$ reflect low and uncontamination to moderately contamination of the river sediment.
\end{abstract}

Keywords: Heavy metals, sediment, season, enrichment factor, geo-accumulation index, pollution load index

\section{Introduction}

Water sediments are normally the final pathway and repositories for natural and anthropogenic components produced or derived to the environment. Sediment quality is a good indication of pollution in water column, where it tends to concentrate the heavy metals and other organic pollutants [1]. Sediment is the loose sand, clay, silt and other soil particles that settle at the bottom of body of water [2]. Erosion of bedrock and soils leads to accumulation of sediments of past or on-going natural and anthropogenic processes and components. Sediments serves as a metal pool that can release metals to the overlying water via natural or anthropogenic processes, causing potential adverse health effects to the ecosystems $[3,4.5,6]$. Many studies have revealed the distribution, enrichment, accumulation and seasonal variation of heavy metals in soil [7, 8, 9, 10, 11, 12].

Our assessment of the sediment contamination was based on degree of contamination using the enrichment factor (EF), the geo-accumulation index $\left(\mathrm{I}_{\text {geo }}\right)$ and pollution load index $[13,14,15,16,17]$. The aim of this study was to assess the status of heavy metals in sediments of Elemi River in south-western, Nigeria using some tools like Enrichment factor (EF), pollution load index (PLI) and geo-accumulation indexes ( $\left.\mathrm{I}_{\text {geo }}\right)$.

\section{Materials and Methods}

2.1 Study area

Elemi river with 355 meters terrain elevation above sea level is located at latitude $7^{0} 37^{\prime} 0.26^{\prime \prime} \mathrm{N}$ and longitude $5^{0} 17^{\prime} 48.19$ ' E in Ekiti State, South-western, Nigeria.

\subsection{Sampling}

Sediment samples were randomly collected at ten different locations along the course of the river. Dry season samples were collected in December, 2015 while the wet season in May, 2016. The sediment samples were collected using a Shipek Grab Sampler. The samples collected were stored in clean plastic bottles in a cold container. The samples were later air-dried, grounded and sieved through $2 \mathrm{~mm}$ mesh size and stored in plastic bottles prior to analysis. 10 samples were collected for each season. To determine the expected natural background levels, sediment (control) samples were collected and analyzed from the bank of the river, areas remotely located from anthropogenic inputs.

\subsection{Sample analysis}

2.3.1 Physico-chemical analysis of sediments

\subsubsection{Determination of $\mathrm{pH}$}

$\mathrm{pH}$ of the sediment was determined by dissolving the sediment in distilled/deionized at ratio 1:5 in a 50 $\mathrm{mL}$. The beaker was allowed to stand for 30 min during which it was stirred with a glass rod occasionally. The $\mathrm{pH}$ meter was probed into the mixture and $\mathrm{pH}$ value recorded.

\subsubsection{Determination of organic matter}

The wet oxidation method of walkley and black described by Schulte [18] was used for organic matter content. 


\subsubsection{Determination of heavy metals content of sediment}

For the heavy metals, a $1.0 \mathrm{~g}$ aliquot sediment sample was digested with $15 \mathrm{~mL}$ of a high purity concentrated $7 \mathrm{~mL}-\mathrm{HF}+5 \mathrm{~mL}-\mathrm{HNO}_{3}+3 \mathrm{~mL}-\mathrm{HCl}$ acid mixture on a hot plate at about $110^{\circ} \mathrm{C}$ for 6 hours within a fume cupboard. After cooling to room temperature, the filtrate was dissolved in $0.5 \mathrm{M} \mathrm{HNO}_{3}$ and transferred into $100 \mathrm{ml}$ volumetric flask and made up to mark with de-ionized water. A reagent blank (without sample) was prepared following the step described for sample preparation. The sample solution and blank were analyzed for the concentration of heavy metals ( $\mathrm{Cd}, \mathrm{Cr}, \mathrm{Fe}, \mathrm{Zn}, \mathrm{Pb}, \mathrm{Cu}$ and $\mathrm{Mn}$ ), using Atomic Absorption Spectrophotometer AAS (Perkin Elmer, Model 306). Duplicates were employed to test for precision, accuracy and reagent purity used in the analytical procedures.

\subsection{Statistical analysis}

Relationships between the metals were determined by bivariate correlation using the Pearson correlation coefficient in SPSS 15.

\subsection{Physico-chemical parameters}

\section{Results and Discussion}

The mean $\mathrm{pH}$ and organic matter content in the sediment samples for both seasons are shown in Table 1. Average $\mathrm{pH}$ of 6.80 and 6.60 were observed for dry and wet seasons. The results showed that the sediment samples were slightly acidic. The average $\mathrm{pH}$ of the control samples was 6.50 and 6.30 for dry and wet seasons respectively while the \%O.M for control samples was 2.70 and $2.90 \%$ for dry and wet seasons. About $2.97 \%$ and $3.32 \%$ average organic matter content were recorded during the dry and wet seasons. Moderate levels of organic content have been reported to indicate high mineral content of soils [19].

\subsection{Concentration of heavy metals}

The concentration range, mean and standard deviation of the heavy metals in the sediment samples for both seasons are shown in Table 2 . The concentration of the heavy metals ranged from $0.18-5.13 \mathrm{mg} / \mathrm{kg}$ and $0.23-5.05 \mathrm{mg} / \mathrm{kg}$ during the dry and wet season respectively. A clear variation was observed for heavy metals concentration with $\mathrm{Cd}(0.32-0.62 \mathrm{mg} / \mathrm{kg}), \mathrm{Cr}(0.18-0.64 \mathrm{mg} / \mathrm{kg}), \mathrm{Fe}(0.96-2.19 \mathrm{mg} / \mathrm{kg}), \mathrm{Zn}(2.16-3.74$ $\mathrm{mg} / \mathrm{kg}), \mathrm{Pb}(0.88-1.21 \mathrm{mg} / \mathrm{kg}), \mathrm{Cu}(2.61-5.13 \mathrm{mg} / \mathrm{kg})$ and $\mathrm{Mn}(1.08-1.54 \mathrm{mg} / \mathrm{kg})$ during the dry season while $\mathrm{Cd}(0.15-0.36 \mathrm{mg} / \mathrm{kg}), \mathrm{Cr}(0.20-0.40 \mathrm{mg} / \mathrm{kg}), \mathrm{Fe}(0.46-1.36 \mathrm{mg} / \mathrm{kg}), \mathrm{Zn}(1.73-2.71 \mathrm{mg} / \mathrm{kg}), \mathrm{Pb}(0.73-1.06$ $\mathrm{mg} / \mathrm{kg}), \mathrm{Cu}(4.53-6.00 \mathrm{mg} / \mathrm{kg})$ and $\mathrm{Mn}(1.80-2.16 \mathrm{mg} / \mathrm{kg})$ during the wet season. The mean heavy metal level during the dry season were in the order; $\mathrm{Cu}>\mathrm{Zn}>\mathrm{Fe}>\mathrm{Mn}>\mathrm{Pb}>\mathrm{Cd}>\mathrm{Cr}$ while the wet season were in the order; $\mathrm{Cu}>\mathrm{Zn}>\mathrm{Mn}>\mathrm{Pb}>\mathrm{Fe}>\mathrm{Cr}>\mathrm{Cd}$. The variation in the levels of heavy metals may be attributed to adsorption, sedimentation and flocculation dynamics which mostly occurs during the dry season. The $\mathrm{Zn}$ and $\mathrm{Pb}$ level in this study were comparably similar to what was reported by Adefemi et al. [21] while Fe and Mn were lower with higher level of $\mathrm{Cu}, \mathrm{Cd}$ and $\mathrm{Cr}$ as compared to other heavy metals in four major dams in Ekiti State, Nigeria.

\section{.3 Indices of pollution}

Contamination factor (CF), enrichment factor (EF) and pollution load index (PLI) were applied to assess the heavy metal contamination in Elemi River sediments. The results of CF and PLI are depicted in Table 3. In order to assess the state of contamination of metals in the sediments, Tomllinson's Pollution Load Index (PLI) [13] and average natural background (control samples) concentration of the metals were used. Pollution Load Index (PLI) is the number of times by which the metal content in the sediments exceeds the average natural background concentration, and gives a summative indication of the overall level of heavy metal toxicity in a particular sample.

The PLI is obtained as a contamination factor (CF) of each metal with respect to the natural background value taken as control sample in the sediment [22].

$\mathrm{CF}=\frac{\mathrm{C} \text { sample }}{\mathrm{C} \text { background }}$

PLI $=\sqrt[n]{\mathrm{CF}_{1} \times \mathrm{CF}_{2} \times \mathrm{CF}_{3} \times \ldots \mathrm{CF}_{\mathrm{n}}}$

Where $\mathrm{CF}=$ contamination factor; $\mathrm{n}=$ number of metals; $\mathrm{C}_{\mathrm{sample}}=$ mean metal concentration in polluted sediments; $\mathrm{C}_{\text {background }}=$ mean natural background value of the metal

The contamination factor ranged from $0.56(\mathrm{Fe})$ to $2.30(\mathrm{Cd})$ and $0.27(\mathrm{Fe})$ to $1.87(\mathrm{Cu})$ during the dry and wet seasons with higher levels in most metals during the dry season except $\mathrm{Cu}$ and $\mathrm{Mn}$. The results showed that the contamination factor value for $\mathrm{Fe}, \mathrm{Pb}$ and $\mathrm{Mn}$ for both seasons were low $(<1)$ while $\mathrm{Cd}, \mathrm{Cr}, \mathrm{Zn}$ and $\mathrm{Cu}$ showed $>1$ in both seasons due to indiscriminate waste disposal and runoff of agricultural waste. 
The pollution load index (PLI) was below unity $(<1)$ during the wet season while the dry season was a bit greater $(>1)$. This shows that Elemi River sediment had greater load of the heavy metals during the dry season. The low PLI recorded in the wet season could be attributed to the dilution factor.

The extent of Elemi River sediment contamination was also assessed using the Enrichment Factor (EF) and geo-accumulation index ( $\left.\mathrm{I}_{\text {geo }}\right)[15,16,17]$. EF was used to assess the relative contributions of natural and anthropogenic heavy inputs to the sediments $[8,9,17,23]$. EF has also been used as an indication of degree of pollution or contamination or both $[24,25]$. EF is expressed as:

$$
\mathrm{EF}=\frac{(\mathrm{X} / \mathrm{Fe}) \text { sediment }}{(\mathrm{X} / \mathrm{Fe}) \text { backgro und }}
$$

Where $(\mathrm{X} / \mathrm{Fe})_{\text {sediment }}$ is the ratio of heavy metal $(\mathrm{X})$ to $\mathrm{Fe}$ in the sample of interest, and $(\mathrm{X} / \mathrm{Fe})_{\text {background }}$ is the natural background value of the metal Fe ratio.

EF values close to unity indicate crusted origin, those less than 1.0 suggest a possible mobilization or depletion of metals, while EF > 1.0 indicates that the element is of anthropogenic origin [26]. Table 4 showed the Enrichment values and geo-accumulation classes of the metals. The EF during the dry season ranged from 1.05 4.17 while the wet season ranged from $1.70-6.83$. Birth [27] suggested some categories of metals with respect to natural background concentration; $\mathrm{EF}<1$ indicates no enrichment, $\mathrm{EF}<3$ is minor enrichment, $\mathrm{EF}$ of $3-5$ is moderate, EF of 5-10 is moderately severe enrichment, EF of $10-25$ is severe enrichment, EF of $25-50$ is very severe enrichment and EF > 50 is extremely severe enrichment. The study showed minor enrichment of $\mathrm{Mn}, \mathrm{Cu}$, $\mathrm{Pb}, \mathrm{Zn}$ and $\mathrm{Cr}$ in the sediments during the dry season while $\mathrm{Cd}$ showed moderately enrichment. In wet season, $\mathrm{Pb}$ showed minor enrichment; $\mathrm{Cd}, \mathrm{Cr}, \mathrm{Zn}$ and $\mathrm{Mn}$ were moderately enriched while $\mathrm{Cu}$ showed moderately severe enrichment. The variation in the EF could be attributed to seasonal variation, nature of the waste been dumped in the river and physicochemical properties of the river sediment. EF of greater than 1 from the study indicates that all the metals are of probable anthropogenic origin.

$I_{\text {geo }}$ values for the metals studied were calculated using the Muller's [28] expression;

$$
\mathrm{I}_{\text {geo }}=\log _{2}\left(\frac{\mathrm{Cx}}{1.5 \mathrm{Bx}}\right)
$$

Where $\mathrm{C}_{\mathrm{x}}$ is the measured content of the metal $\mathrm{X}$ and $\mathrm{B}_{\mathrm{x}}$ is the natural background concentration of metal X., 1.5 is the background matrix correction factor due to lithogenic effects.

The results (Table 4) in most cases showed very low values $(<0)$. $\mathrm{Zn}, \mathrm{Pb}$ and $\mathrm{Mn}$ were $<0$ in both seasons while $\mathrm{Cd}$ and $\mathrm{Cr}$ in dry and $\mathrm{Cu}$ during the wet season showed $<1.0$. The $\mathrm{I}_{\text {geo }}$ scale consists of seven grades $(0-6)$ ranging from uncontaminated to very highly contaminated. $<0$ is practically uncontaminated; 0 1 , uncontaminated to moderately contaminated; $1-2$, moderately contaminated; $2-3$, moderately to strongly contaminated; $3-4$, strong contaminated; $4-5$, strongly to extremely strongly contaminated; $>5$, extremely contaminated $[28,29]$. Generally, $\mathrm{Zn}, \mathrm{Pb}$ and $\mathrm{Mn}$ in both seasons were practically uncontaminated while $\mathrm{Cd}$ and $\mathrm{Cr}$ in dry season and $\mathrm{Cu}$ in wet season are uncontaminated to moderately contaminated. Therefore, the $\mathrm{I}_{\text {geo }}$ classes of the heavy metals in the sediments of Elemi River are uncontaminated as a result of human activities on the river.

Pearson's correlation matrixes of heavy metals in the sediment for both seasons are shown in Tables 5 and 6. The correlation coefficient between $\mathrm{Cr}$ and Fe during the dry season (0.834) indicates a strong positive linear correlation at the 0.05 significance level and a common origin of these metals. Fe and $\mathrm{Cd}$ formed another highly correlated pair with a significant correlation coefficient of 0,834 , suggesting they probably originated from some common sources. The concentrations of $\mathrm{Zn}-\mathrm{Fe}(-0.738)$ and $\mathrm{Zn}-\mathrm{Cu}(-0.816)$ in dry and wet seasons showed strong significant negative correlation at 0.05 and 0.01 confident level. The lack of significant linear correlation between $\mathrm{Cd}-(\mathrm{Cr}, \mathrm{Fe}, \mathrm{Pb}, \mathrm{Mn}), \mathrm{Fe}-(\mathrm{Pb}, \mathrm{Cu}), \mathrm{Pb}-(\mathrm{Cu}, \mathrm{Mn})$ in dry season; $\mathrm{Cr}-\mathrm{Cd}, \mathrm{Fe}-(\mathrm{Cd}, \mathrm{Cr}), \mathrm{Zn}-(\mathrm{Cd}$, $\mathrm{Cr}, \mathrm{Fe}), \mathrm{Pb}-\mathrm{Cr}$, and $\mathrm{Cu}-\mathrm{Mn}$ in wet season suggests that its sources were quite different from those of the others.

\section{Conclusion}

The study revealed contamination of Elemi River with the selected metals. Highest heavy metal concentration were found during the dry season as compared to the wet season for most metals except in $\mathrm{Cu}$ and $\mathrm{Mn}$. CF values of $\mathrm{Cd}, \mathrm{Cr}, \mathrm{Zn}$ and $\mathrm{Cu}$ were high (>1) for both seasons due to influence of external discrete source like waste dump and agricultural runoff. The enrichment factor showed minor enrichment to moderately enrichment for the studied metals. The geo-accumulation index data of the sediments reflected uncontaminated to moderately contaminated of Elemi river. The need for continuous monitoring and further studies on the levels of these heavy metals should be encouraged to ascertain long-term effects of anthropogenic impact and agricultural runoff. 


\section{References}

[1]. S.M. Saeed and I.M. Shaker, Assessment of heavy metals pollution in water and sediments and their effect in Oreochromis niloticus in the Northern Delta lakes, Egypt. $8^{\text {th }}$ International Symposium of Tilapia in Aquaculture, 2008, 475-490.

[2]. O.A. Davies and J.F.N. Abowei, Sediment quality of lower reaches of Okpoka Creek, Niger delta, Nigeria. European Journal of Scientific Research, 26 (3), 2009, 437-442.

[3]. W.W. Dickinson, G.B. Dunbar and H. McLead, Heavy metal history from cores in Wellington Harbour, New Zealand. Environmental Geology, 27, 1996, 59-69. Doi:10/1007/BF00770603.

[4]. D.J. Poulton, W.A. Morris and J.P. Coakley, Zonation of contaminated bottom sediments in Hamilton harbour as defined by statistical classification techniques. Water Quality Research Journal of Canada, 31, 1996, 505-528.

[5]. O.S. Fatoki and S. Mathabatha, An assessment of heavy metal pollution in the East London and Port Elizabeth harbours. Water S.A., 27, 2001, 233-240.

[6]. S. McCready, G.F. Birch and E.R. Long, Metallic and organic contaminants in sediments of Sydney harbour, Australia and vicinitya chemical dataset for evaluating sediment quality guidelines. Environment International, 32, 2006, 455-465. Doi:10.1016/j.envint.2005.10.006.

[7]. K.M. Huang and S. Lin, Consequences and implication of heavy metal spatial variations in sediments of the Keelung River drainage basin, Taiwan. Chemosphere, 53, 2003, 1113-1121. Doi:10.1016/S0045-6535(03)00592-7.

[8]. J. Morillo, J. Usero and I. Gracia, Heavy metal distribution in marine sediments from the southwest coast of Spain. Chemosphere, 55, 2004, 431-442. Doi:10.1016/j.chemosphere.2003.10.047.

[9]. P. Adamo, M. Arienzo, M. Imperato, D. Naimo, G, Nardi and D. Stanzione, Distribution and partition of heavy metals in surface and sub-surface sediments of Naples City Port. Chemosphere, 61, 2005, 800-809. http://dx.doi.org/10.1016/j.chemosphere.2005.04.001

[10]. R.K. Ranjan, A.L. Ramanathan, G. Singh and S. Chidambaram, Assessment of metal enrichments in tsunamigenic sediments of Pichavaram mangroves, Southeast coast of India. Environ. Monit. Assess; 147(1-3), 2008, 389-411.doi.10/007/s1066-007-0128.

[11]. J.P. Essien, Ecology and Physiological diversity of heterotrophic and hydrocarbon utilizing microorganisms in sediments of the Niger Delta Mangrove Swamp ecosystem. Ph.D. Thesis, University of Calabar, Calabar, Nigeria, 2007, p 500.

[12]. E.P. Nobi, E. Dilipan, T. Thangaradjou, K. Sivakumar and L. Kannan, Geochemical and geo-statistical assessment of heavy metal concentration in the sediments of different coastal ecosystems of Andaman Islands, India Estuarine coastal shelf SW; 87, 2010, 253264.

[13]. D.C. Tomllinson, J.G. Wilson, C.R. Harris and D.W. Jeffrey, Problems in the assessment of heavy metals levels in Estuaries and the formation of pollution index. Helgolander Wissenchaftliche Meeresuntersuchungen, 33, 1980, 566-569, http://dx.doi.org/10.1007/BF02414780

[14]. M. Aloupi and M.O. Angelidis, Geochemistry of natural and anthropogenic metals in the coastal sediments of the Island of Les vos, Aegean Sea. Environmental Pollution, 113, 2001, 211-219.

[15]. P. Woitke, J. Wellmitz, D. Helm, P. Kube, P. Lepom and P. Litherty, Analysis and assessment of heavy metal pollution in suspended solids and sediments of the river Danube, Chemosphere, 51, 2003, 633-642.

[16]. M.S. Reddy, S. Basha, V.G.S. Kumar, H.V. Joshi and G. Ramachandraiah, Distribution, enrichment and accumulation of heavy metals in coastal sediments of Alang-Sosiya Ship Scrapping Yard, India. Marine Pollution Bulletin, 48, 2004 , $1055-1059$. http://dx.doi.org/10.1016/j.marpolbul.2001.12.011

[17]. K, Selvaraj, V.R. Mohan and P. Szefer, Evaluation of metal contamination in coastal sediments of the bay of Bengal, India: Geochemical and statistical approaches. Marine Pollution Bulletin, 49, 2004, 174-185. http://dx.doi.org/10.1016/j.marpolbul.2004.02.006

[18]. E.E. Schulte, Recommended soil organic matter test. In Recommended soil testing procedures for the North-eastern United State $2^{\text {nd }}$ ed. 1995.[20]. S.V. Matagi, D. Swai and R. Mugabe, Heavy metal removal mechanisms in wetlands. African J. Tropical Hydrobiol. Fisher, 8, 1998, 23-35.

[19]. A.J.M. Baker, R.D. Mcgrawth and J.A.C. Smith, Metal hyperaccumulators plants: A review of the ecology and physiology of a biological resource of phytoremediation of metal polluted soils. In: N. Tarry and G. Banuelos (ed): Phytoremediation of contaminated soil and waters. Lewis publishers, Boca Raton, FL., 2000, 85-107.

[20]. S.V. Matagi, D. Swai and R. Mugabe, Heavy metal removal mechanisms in wetlands. African J. Tropical Hydrobiol. Fisher, 8, 1998, 23-35.

[21]. O.S. Adefemi, O. Olaofe and S.S. Asaolu, Seasonal variation in heavy metal distribution in the sediment of major dams in Ekiti state. Pakistan Journal of Nutrition, 6, 2007, 705-707.

[22]. E. Angulo, The Tomllinson pollution load index applied to heavy metals "Mussel-Watch" data: a useful index to assess coastal pollution. The Science of the Total Environment, 187, 1996, 19-56. doi:10.1016/0048-9697(96)05128-5.

[23]. J. Vald'es, G. Vargas, A. Sifeddine, L. Ortlieb and M. Guinez, Distribution of enrichment of heavy metals in Mejillones Bay $\left(23^{\circ} \mathrm{S}\right)$, Northern Chile: geochemical and statistical approach. Marine Pollution Bulletin, 50, 2005, 1558-1568.

[24]. J. Zheng and C.L. Liu, Riverine compositionand estuarine geochemistry of particulate metals in China weathering features, anthropogenic impact and chemical fluxes. Estaurine, Coastal and Shelf Science, 54, 2002, 1051-1070.

[25]. H. Feng, X, Han, W, Zhang and L. Yu, A preliminary study of heavy metal contamination in Yangtze River intertidal zone due to urbanization. Marine Pollution Bulletin, 49, 2004, 910-915. Doi:10.1016/j.marpolbul.2004. 06.014.

[26]. P. Zsefer, G.P. Glasby, K. Sefer, J. Pempkowiak and R. Kaliszan, Heavy-metal pollution in superficial sediments from the southern Baltic Sea off Poland. Journal Environmental Science Health, Part A: Environmental Science and Engineering and Toxicology, 31, 1996, 2723-2754.

[27]. G.A. Birth, A scheme for assessing human impacts on coastal aquatic environments using sediments, Woodcoffe, C.D. and Furness, R.A., Eds., Coastal GIS 2003, Wollongong University Papers in Centre for Maritime Policy, 14, Wollongong.

[28]. [28]. G. Muller, Schwermetalle in den sediments des Rheins-Veran-derngren seitt, 1971. Umschan, 79, 1979, 778-783. 
Distribution, enrichment and accumulation of heavy metals in Elemi River sediments, ...

Table 1: Mean values of $\mathrm{pH}$ and Organic matter content of sediment samples

\begin{tabular}{|l|cc|cc|}
\hline & \multicolumn{2}{|c|}{$\mathrm{pH}$} & \multicolumn{2}{c|}{$\% \mathrm{OM}$} \\
& E sediment & Control & E sediment & Control \\
\hline Dry & $6.80 \pm 0.20$ & $6.50 \pm 0.10$ & $2.97 \pm 0.24$ & $2.70 \pm 0.15$ \\
\hline Wet & $6.60 \pm 0.10$ & $6.30 \pm 0.20$ & $3.32 \pm 0.46$ & $2.90 \pm 0.20$ \\
\hline
\end{tabular}

E=Elemi River

Table 2: Ranges (Mean $\pm \mathrm{SD}$ ) of heavy metals concentration $(\mathrm{mg} / \mathrm{kg})$ in Elemi sediment

\begin{tabular}{|l|l|l|}
\hline Heavy metals & Dry season (December, 2015) & Wet season (May, 2016) \\
\hline $\mathrm{Cd}$ & $0.32-0.62(0.45 \pm 0.09)$ & $0.15-0.36(0.23 \pm 0.07)$ \\
\hline $\mathrm{sCr}$ & $0.18-0.64(0.42 \pm 0.14)$ & $0.20-0.40(0.31 \pm 0.17)$ \\
\hline $\mathrm{Fe}$ & $0.96-2.19(1.48 \pm 0.42)$ & $0.46-1.36(0.72 \pm 0.30)$ \\
\hline $\mathrm{Zn}$ & $2.16-3.74(3.15 \pm 0.52)$ & $1.73-2.71(2.20 \pm 0.39)$ \\
\hline $\mathrm{Pb}$ & $0.88-1.21(1.09 \pm 0.57)$ & $0.73-1.06(0.86 \pm 0.09)$ \\
\hline $\mathrm{Cu}$ & $2.61-5.13(3.26 \pm 0.97)$ & $4.53-6.00(5.05 \pm 0.52)$ \\
\hline $\mathrm{Mn}$ & $1.08-1.54(1.35 \pm 0.24)$ & $1.80-2.16(1.98 \pm 0.13)$ \\
\hline
\end{tabular}

Table 3: Mean concentration ( $\mathrm{mg} / \mathrm{kg}$ ), contamination factor of Elemi sediment and pollution load index (PLI) of the metals.

\begin{tabular}{|l|l|l|l|l|l|}
\hline Heavy Metals & \multicolumn{4}{l|}{ Mean Concentration } & \multicolumn{2}{l|}{$\begin{array}{l}\text { Contamination Factor (Natural } \\
\text { Background Concentration) }\end{array}$} \\
\hline & Dry & Wet & Dry & Wet & \\
\hline $\mathrm{Cd}$ & 0.45 & 0.23 & 2.30 & 1.21 & $0.19 \pm 0.7$ \\
\hline $\mathrm{Cr}$ & 0.42 & 0.31 & 1.56 & 1.15 & $0.27 \pm 0.4$ \\
\hline $\mathrm{Fe}$ & 1.48 & 0.72 & 0.56 & 0.27 & $2.63 \pm 1.6$ \\
\hline $\mathrm{Zn}$ & 3.15 & 2.26 & 1.50 & 1.08 & $2,10 \pm 1.3$ \\
\hline $\mathrm{Pb}$ & 1.09 & 0.86 & 0.59 & 0.46 & $1.85 \pm 0.2$ \\
\hline $\mathrm{Cu}$ & 3.26 & 5.05 & 1.21 & 1.87 & $2.70 \pm 2.7$ \\
\hline $\mathrm{Mn}$ & 1.35 & 1.98 & 0.66 & 0.97 & $2.04 \pm 0.6$ \\
\hline $\mathrm{PLI}$ & & & 1.05 & 0.86 & \\
\hline
\end{tabular}

Table 4: EF values and $\mathrm{I}_{\mathrm{geo}}$ classes of metals in sediments of Elemi river.

\begin{tabular}{|l|l|l|l|l|}
\hline Heavy metals & \multicolumn{3}{|l|}{ Enrichment Factor $(\mathrm{EF})$} & \multicolumn{2}{l|}{ Geo-accumulation index $\left(\mathrm{I}_{\text {geo }}\right)$} \\
\hline & Dry & Wet & Dry & Wet \\
\hline $\mathrm{Cd}$ & 4.17 & 4.42 & 1 & 0 \\
\hline $\mathrm{Cr}$ & 2.76 & 4.19 & 1 & 0 \\
\hline $\mathrm{Zn}$ & 2.67 & 3.93 & 0 & 0 \\
\hline $\mathrm{Pb}$ & 1.05 & 1.70 & 0 & 0 \\
\hline $\mathrm{Cu}$ & 2.14 & 6.83 & 0 & 1 \\
\hline $\mathrm{Mn}$ & 1.17 & 3.54 & 0 & 0 \\
\hline
\end{tabular}

Table 5: Pearson's correlation matrix of heavy metals in the sediments during the dry season

\begin{tabular}{|l|c|c|c|c|c|c|c|}
\hline & $\mathrm{Cd}$ & $\mathrm{Cr}$ & $\mathrm{Fe}$ & $\mathrm{Zn}$ & $\mathrm{Pb}$ & $\mathrm{Cu}$ & $\mathrm{Mn}$ \\
\hline $\mathrm{Cd}$ & 1 & 0.089 & 0.121 & -0.457 & 0.020 & -0.026 & 0.360 \\
\hline $\mathrm{Cr}$ & & 1 & $0.700^{*}$ & -0.473 & -0.319 & -0.270 & -0.064 \\
\hline $\mathrm{Fe}$ & & & 1 & $-0.738^{*}$ & 0.148 & 0.081 & -0.251 \\
\hline $\mathrm{Zn}$ & & & & 1 & -0.326 & -0.173 & -0.183 \\
\hline $\mathrm{Pb}$ & & & & & 1 & 0.288 & 0.421 \\
\hline $\mathrm{Cu}$ & & & & & & 1 & -0.388 \\
\hline $\mathrm{Mn}$ & & & & & & & 1 \\
\hline
\end{tabular}

$* \mathrm{p}<0.05 ; * * \mathrm{p}<0.01$

Table 6: Pearson's correlation matrix of heavy metals in the sediments during the wet season

\begin{tabular}{|l|c|c|c|c|c|c|c|}
\hline & $\mathrm{Cd}$ & $\mathrm{Cr}$ & $\mathrm{Fe}$ & $\mathrm{Zn}$ & $\mathrm{Pb}$ & $\mathrm{Cu}$ & $\mathrm{Mn}$ \\
\hline $\mathrm{Cd}$ & 1 & 0.155 & $0.834^{* *}$ & 0.436 & -0.018 & -0.495 & -0.390 \\
\hline $\mathrm{Cr}$ & & 1 & 0.296 & 0.029 & 0.277 & -0.081 & -0.505 \\
\hline $\mathrm{Fe}$ & & & 1 & 0.158 & -0.198 & -0.316 & -0.125 \\
\hline $\mathrm{Zn}$ & & & & 1 & -0.268 & $-0.816^{* *}$ & -0.183 \\
\hline $\mathrm{Pb}$ & & & & & 1 & 0.014 & -0.520 \\
\hline $\mathrm{Cu}$ & & & & & & 1 & 0.486 \\
\hline $\mathrm{Mn}$ & & & & & & & 1 \\
\hline
\end{tabular}

$* \mathrm{p}<0.05 ; * * \mathrm{p}<0.01$ 